\title{
CONSTRUCTION OF HEDONIC PRICE INDEX FOR THE “MOST LIQUID” POLISH PAINTERS
}

Krzysztof Kompa, Ph.D.

Warsaw University of Life Sciences

Department of Econometrics and Statistics

Nowoursynowska 166, 02-787 Warszawa, Poland

e-mail: krzysztof_kompa@sggw.pl

Dorota Witkowska, Ph.D., Full Professor

University of Lodz

Department of Finance and Strategic Management

Matejki 22/26, 90-237 Łódź, Poland

e-mail:dorota.witkowska@uni.lodz.pl

Received 24 March 2014, Accepted 15 December 2014

\begin{abstract}
Art market has been developing in Poland and the first Art Fund was established in 2011. Therefore it seems that investment in art can be considered as alternative form by Polish investors. In order to decide whether art is a good investment, it is necessary to evaluate expected returns which might be obtained from such investment thus an art price index should be developed. The aim of the paper is to discuss artworks as investment assets and evaluate price index of paintings produced by 11 Polish artists whose artworks were traded the most often on auctions that were held in Poland in the years 2007-2010. In our research, employing data concerning 750 objects, we apply the hedonic index methodology to estimate returns from the paintings market. The results of our investigation show that hedonic quality adjustment essentially influences evaluation of artwork prices therefore we propose the aggregated hedonic index which might better describe situation at the art market than the hedonic index biased by the specification of a single model.
\end{abstract}

Keywords: art market, hedonic price index, investment.

JEL classification: C43, C51, G10, Z11. 


\section{Introduction}

Investments in art, recognized by critics, has been nothing new. However in the past artbuyers were connoisseurs thus they were well prepared to make such investments, and number of investors was quite limited. At present the share of investors in the society has been increasing regardless their knowledge regarding financial or other type of the investment instruments since in well-developed economies everybody participating at least in pension funds seems to be an investor.

The art market in Poland started to develop at the end of the 19th century until World War II. Under the communist system the art market in Poland practically did not exist. Although in that time several art galleries and artist associations were operating buying and selling art pieces, mostly currently produced by domestic artists or the ones from other soviet bloc countries. Transformation of the economic system also affected the art market since last two decades were characterized by changes in the income distribution and the structure of consumption that caused the increasing interest in art market in the Polish society.

Therefore, in the paper, the attempt to evaluate returns from investment in Polish paintings market is made. In the research we consider transactions that took place during auctions, which held in Poland only. Commonly used methods to construct art price indexes are repeat-sales regression and hedonic regression ${ }^{1}$. Limited scale of the art market in Poland does not allow to apply the repeated sale approach for the price index construction, therefore the hedonic approach is employed. The aim of research is evaluation of the art price index on the basis of data concerning the selected sample of paintings sold at auctions held by auction houses and foundations in the years 2007-2010. We construct several hedonic regression models for different samples of paintings and hedonic variables sets that are selected according to different criteria.

\section{Art as investment asset}

Situation at financial markets encourages investors to look for alternative investments to diversify their portfolio. The relatively new approach toward investing is to concern pieces of art as an investment instrument or a collateral. There is more and more literature concerning artworks as investment opportunity for investors ${ }^{2}$.

Artworks as investment assets are characterized by some features. (1) The current market value is difficult to evaluate since there is no "natural value", which could be used as reference or fair value. The price of artwork is limited only by the amount of money that collectors are 
willing and able to pay for $\mathrm{it}^{3}$. (2) Art investments are undivided and illiquid in comparison to "classical" financial assets. (3) Artworks are often expensive, also cost of purchase and sale may be high (from 10 to 25 percent of hammer price while transaction costs on financial markets are about $1 \%$ of the price) and they seem to be long-lasting investments.

There are also several risks (regardless the risk of price variability of investment instruments) specific for the art market ${ }^{4}$. (1) Buyer can never be certain whether the purchased object is original (i.e. not a copy or forgery). And even if the artwork is an original piece one never knows who a painter was: the master himself, the circle, the school or the painting could have been made only in the style of a grand master ${ }^{5}$. (2) The quality of paintings, which have been repainted, damaged, not properly renovated or stored, may cause the decline of their value. (3) Owners of art pieces can be afraid that the masterpieces (that they possess) might be stolen, destroyed (by fire, revolution, etc.) or seized by government as a part of "national heritage". (4) Possession of valuable art can cause the necessity to pay additional taxes (sale or property taxes) and governments may impose new export restrictions. (5) Tastes and fashions change over time and art market is characterized by extreme heterogeneity thus one never knows if a certain artist will not be "fallen from fashions" in the future ${ }^{6}$. (6) Art belongs to the group of luxury goods and it's price is very sensitive on general economic situation and income changes? (7) Behavioral anomalies seem to play an important role in the art market since collectors are usually not willing to sell pieces of art from their collections and they tend to buy art produced by domestic artists.

In order to decide whether art is a good investment, it is necessary to evaluate the expected returns which might be obtained from such investment, thus an art price index should be developed. The major motivation behind the construction of art price indexes is ${ }^{8}$ : (1) to measure financial performance of art, relative to other alternative forms of investment, (2) to check whether adding art to a diversified market portfolio can lower the overall risk and/or increase the rate of return, and (3) to outline general trends on the art market. The construction of the art price index dedicated to the certain market requires several decisions concerning: selection of the index methodology and selection of the sample i.e. its size and the way of the object selection. There are several methods and indexes which can be used to analyze changes of prices or returns from the art market, such as naive price index, repeat-sales, average price (geometric mean), composite price (basket) index, and hedonic index ${ }^{9}$.

The repeat sales methodology considers only those artworks that were sold at least twice in the investigated period, and their prices were registered. Thus it requires a transparent and liquid market. Ginsburgh et al. ${ }^{10}$ argue that repeat-sales regression should not be applied to 
periods shorter than 20 years, since the number of observations may be too small to obtain reliable results. The main advantage of hedonic index approach is that it may consider all traded objects.

The naïve art price index is constructed using average and median auction prices. In this method, a basket of representative paintings is created and tracked over time. This approach avoids the repeated sales restrictions but requires instead aggregation on some a priori criteria in order to construct so-called "average painting"11.

The problem of the sample selection is crucial in construction the fixed basket of representative artworks that must be made by experts. However, it appears also in the application of other methods and it has been known from literature since many different criteria of the artwork selection are employed, beginning from selection of the mediums ${ }^{12}$, to taking objects that belong to the certain collection ${ }^{13}$, or creating the sample from artworks produced in the certain style or period ${ }^{14}$ to works produced by selected authors ${ }^{15}$ or to taking into account "spatial" classification ${ }^{16}$. Such arbitrary choice may be criticized because selected artworks may not be representative for the whole market. The size of the sample depends on the investigated period i.e. time spam when artworks are sold.

\section{Hedonic art price index}

Art price index can be evaluated employing hedonic regression, which is a method for estimating an approximate value of a piece of art adjusting the average price of the artist's works for the qualitative characteristics which are incorporated into the hedonic model. Hedonic price functions are used to predict prices of new goods, adjust for quality change in price indexes and to measure consumer and producer valuations of different products. They describe the relationship between characteristic of a product and its price. The analytic function is determined by distributions of buyers and sellers and their preferences as well as the structure of competition in the market ${ }^{17}$.

Artworks are heterogeneous assets, with a variety of physical and non-physical characteristics that make them unique, including an artist's reputation, materials used, the period of production and subjective traits like quality. Therefore the price of an artwork depends on these characteristics. In hedonic approach ${ }^{18}$, the value attached to each one of the attributes, that are deemed to be significant in the determination of the price, is estimated and the price index is evaluated employing so called hedonic quality adjustment (HQA). The basic formula for hedonic index (HI) is as following: 


$$
H I_{t+1}=\frac{N I_{t+1}}{H Q A_{t+1}}=\frac{\prod_{i=1}^{n}\left(P_{i, t+1}\right)^{1 / n} / \prod_{i=1}^{m}\left(P_{i, t}\right)^{1 / m}}{H Q A_{t+1}}
$$

where: $N I_{t}$ - naive price index at time $t, P_{i t}$ - the price of the $i$-th artwork at time $t, H Q A_{t}-$ hedonic quality adjustment at time $t$.

The naive price index (NI) describes "average painting" from the aggregation of all artworks that create the sample representing the art market or its segment. The hedonic index allows the tracking of short-term price movements and returns in this market. It gives us a better understanding of how this market performed over the investigated period. The performance of this market can then be compared to investments in traditional financial assets.

Changes in quality, style, mode and type of the artworks are described by the hedonic quality adjustment which is defined as follows:

$$
H Q A_{t+1}=\exp \left[\sum_{j=1}^{k} \hat{\alpha}_{j}\left(\sum_{i=1}^{n} \frac{X_{i j, t+1}}{n}-\sum_{i=1}^{m} \frac{X_{i j, t}}{m}\right)\right]
$$

where: $X_{i j, t}-$ an observation of the $j$-the feature characterizing the $i$-th artwork at time $t, m$ and $n$ are numbers of lots sold in the period $t$ and $t+1$, respectively, $\hat{\alpha}_{j}-$ the parameter estimate of hedonic regression (pooled regression) that usually takes the following form:

$$
\ln P_{i, t}=\alpha_{0}+\sum_{j=1}^{k} \alpha_{j} X_{i j, t}+\sum_{t=1}^{\tau} \beta_{t} Z_{i, t}+\varepsilon_{i, t}
$$

where $\alpha_{\mathrm{j}}, \beta_{t}$ - the coefficient values of the characteristics $X_{j}$ and $Z_{t}, Z_{t}$ - the time dummy variable, which takes the value 1 if the $i$-th painting is sold in the period $t$ and takes the value 0 otherwise, and $\varepsilon_{i t}-$ the disturbance term.

One of the underlying assumptions is that the price of an artwork depends essentially on its quality, which is to a great extent quantifiable. The explanatory variables represent characteristics of the objects, such as the artist, size, format, technique, materials, period, subject of the artwork, signature and the artist's living status or the characteristics related to the sale, including the auctioneer, location and date of sale. These attributes are usually qualitative so they are represented by binary variables in (3). The dependent variable in hedonic models is usually the natural logarithm of the sales price. All auctions relating to an artist are included in the calculation in order to avoid selection bias. The time dummy variables can be annual, semi- 
annual, quarterly or even monthly depending on the frequency of trading. The hedonic approach essentially entails running an Ordinary Least Squares (OLS) regression.

The hedonic regression method therefore controls for quality changes by attributing implicit prices to a set of value-adding characteristics. In other words, hedonic regressions strip the observable characteristics from the artworks to obtain an index reflecting the price of a "standard artwork"19.

Hedonic models require knowledge of the artworks' characteristics and mechanisms driving art prices. The main weakness of this methodology is limitation of attributes used as explanatory variables and arbitrariness of their selection. Therefore application of hedonic index methodology requires decision about (a) the form ${ }^{20}$ of the price index, (b) selection of explanatory variables in the regression model (3), (c) selection of artworks and variables used for art price index evaluation in formulas (1)-(2).

Variable selection is concerned with a great variety of attributes, and its variants which characterize artworks. The variety of attributes makes it impossible to consider all of them in the model if they are represented by binary variables, for instance techniques and mediums, or the subject of the artwork. Other multi-variant variables such as artists or auction houses may be limited to certain authors (for instance well known or representing certain school or period) or auctioneers (for instance the most prestigious). Thus the results of the hedonic index evaluation are dependent on researcher's arbitrary choice and may be distorted by the misspecification of the model or omission of important variables ${ }^{21}$. Therefore we propose to construct the aggregated hedonic index which summarizes different hedonic models specification:

$$
A H I_{t}=\sqrt[K]{\prod_{k=1}^{K} H I_{t, k}}=\frac{N I_{t}}{\sqrt[K]{\prod_{k=1}^{K} H Q A_{t, k}}}=\frac{N I_{t}}{A H Q A_{t}}
$$

where $k(k=1,2, \ldots, K)$ denotes the certain hedonic model, therefore $H Q A_{t, k}$ and $H I_{t, k}-$ the hedonic quality adjustment and index (respectively) evaluated applying parameter estimates of the $k$-th hedonic regression model.

Having price indexes describing price relation in two neighboring periods $t(t=1,2, \ldots, T)$, i.e. $I_{1}, I_{2}, \ldots, I_{t}$, we may calculate the price index $T I_{t}$ concerning price changes in comparison to the first $(t=0)$ period of analysis, i.e.: $T I_{t}=I_{1} \times I_{2} \times \ldots \times I_{t}$. Therefore the total index $T I_{T}$ informs about price movements during the whole period of investigation since it is the relation of prices in the last period $t=T$ in comparison to the first period $t=0$. Then returns from investment in 
art obtained period by period equal $C_{T}=\left(I_{t}-1\right) \times 100 \%$, while total return in the whole analyzed period is $T C_{T}=\left(T I_{T}-1\right) \times 100 \%$. It is also possible to evaluate the average return for the single period taking into account the total returns from the whole period of investigation, employing geometric mean:

$$
G M=\sqrt[T]{\prod_{t=1}^{T} I_{t}}=\sqrt[T]{T I_{T}}
$$

In such a case average return in the single period equals: $G=(G M-1) \times 100 \%$.

\section{Some facts about art market in Poland}

In 2012 the Polish art market value was estimated for 300-350 millions PLN ${ }^{22}$ while auction sales was 60.5 millions PLN $^{23}$, and it was the highest result since 1989. The world art market global sales ${ }^{24}$ equaled 43 billions euro in 2012, therefore the Polish art market is about $0.2 \%$ of the world sales.

Table 1. Structure of the Polish art market in the first half of 2012

by mediums and segments (\%)

\begin{tabular}{|l|c|c|l|r|r|}
\hline \multicolumn{1}{|c|}{ Mediums } & Lots & Value & \multicolumn{1}{c|}{ Segments } & Lots & Value \\
\hline Sculpture & 2 & 1 & Post-war and contemporary & 30 & 31 \\
\hline Photography & 1 & 0 & Ultra-contemporary & 44 & 8 \\
\hline Arts \& Crafts & 10 & 5 & Art before 1945 & 26 & 61 \\
\cline { 1 - 3 } Graphic & 14 & 2 & & & \\
\cline { 1 - 3 } Drawing & 17 & 20 & &
\end{tabular}

Source: own elaboration on the basis of data from Gajewski \& Potocki²5.

The number of art auctions increased from 8 in 1989 to 122 in $2012^{26}$. The structure of the art market in Poland is presented in Table 1. Paintings are the most popular medium of the Polish art market both in the number of lots (56\%) and the value of transactions $(72 \%)$. There are no individual sales organized for Old Masters and Modern Art in Poland, therefore 1945 has been chosed for the main threshold for art market segments because until 1989 all artworks and crafts that had been produced before 1945 were treated as national heritage. The term "ultra-contemporary" is used for young artists (under 40 years old) - 44\% of artworks sold with capitalization of $8 \%$.

According to the Deloitte ${ }^{27}$ report, the average annual return from 800 repeat sales that took place in Poland during the last 20 years, was $25.7 \%$ while in the same time equity returns measured 
by Warsaw Stock Exchange Index WIG20 was only $8.7 \%{ }^{28}$. Annual return from artworks hold longer than 15 years was $46.6 \%$ while investments with the horizon shorter than 5 years gave only $0.2 \%$ profit. Thus the time spam of investments is crucial in the obtained returns.

\section{Empirical results}

Hedonic models are estimated employing data ${ }^{29}$ from auctions of paintings that took place in Poland in the years 2007-2010. The whole sample contains 10,400 objects produced by nearly 3,000 artists who represent different periods and styles, as well as a great variety of techniques. The range of prices is huge - from 20 PLN for a piece produced by J. Jakóbowska (born in 1984) to 1.1 million PLN for an artwork by W. Czachórski (1850-1911), with average price for a single lot of 8,691 PLN and the standard deviation of 33,698 PLN. Therefore here a question arises which traded objects should be taken into account and what is the minimal price for a work to be treated as a piece of art. We have decided to consider only artworks painted by the Polish artists who are selected according to the biggest number of lots sold in the investigated period ${ }^{30}$, and we assume that minimal average price for an artist should be 2,000 PLN. Employing these criteria the sample of paintings is constructed.

\subsection{Description of data and variables}

The biggest number of lots sold in the analyzed period were produced by Jerzy Kossak (91) while the highest value of transactions concerns artworks by Malczewski (more than 1 million PLN). In our sample, the lowest average value for the single artwork were reached by paintings by Nikifor $(2,486$ PLN). The selected sample covers $7.2 \%$ of all the lots and $16.2 \%$ of the turnover registered in the database. Table 2 contains basic information about "the most liquid" painters whose artworks are used in our research.

In our investigation we select several explanatory variables which are usually applied in hedonic models constructed for the art price. They describe an artist's and an exhibitor's reputation, the type and quality of the artwork as well as the conditions of a transaction. Auction house describes the reputation of an auctioneer and this variable is specified as a number of dummies defined name of auctioneer. Reference variant of this variable is other auctioneers. An artist reputation is defined by the name of a painter that is represented by the artist variable, and Wyczółkowski is the reference painter. An a rtist's living status is also often incorporated to hedonic models since when an artist dies the production stops and prices may rise. We assume that living status variable equals 0 if an artist is still living. In our investigation we have also 
created the price class variable that is defined due to the average prices obtained in the whole sample by individual artists, but each object is classified to the certain price class individually to avoid colinearity. There are 4 variants of this variable CLASS_1: more than 73,000 PLN, CLASS_2: from 16,750 PLN to 73,000 PLN, CLASS_3: from 5,817 PLN to 16,750 PLN and CLASS_4: less than 5,817 PLN., the reference variable is CLASS_4. Another variable is the epoch variable that classifies artists regarding the date of their birth, and equals 1 if the painter was born before 1900 .

Table 2. List of Polish painters whose artworks created the sample

\begin{tabular}{|c|c|c|c|c|c|c|}
\hline \multirow{2}{*}{ No. } & \multirow{2}{*}{ Author } & Count & $\begin{array}{l}\text { Value } \\
\text { (PLN) }\end{array}$ & $\begin{array}{c}\text { Average } \\
\text { (PLN) }\end{array}$ & \multicolumn{2}{|c|}{ Year of } \\
\hline & & \multicolumn{3}{|c|}{ of artworks sold in 2007-2010 } & birth & death \\
\hline 1 & Chmieliński Stachowicz Wład. & 55 & 648,200 & 11,786 & 1911 & 1979 \\
\hline 2 & Dominik Tadeusz & 46 & 608,000 & 13,217 & 1928 & - \\
\hline 3 & Dwurnik Edward & 63 & 431,300 & 6,846 & 1943 & - \\
\hline 4 & Erb Erno & 58 & 816,500 & 14,078 & 1890 & 1943 \\
\hline 5 & Kossak Wojciech & 60 & $2,027,500$ & 33,792 & 1856 & 1942 \\
\hline 6 & Wyczółkowski Leon & 61 & $3,848,300$ & 63,086 & 1852 & 1936 \\
\hline 7 & Hofman Wlastimil & 85 & $1,817,050$ & 21,377 & 1881 & 1970 \\
\hline 8 & Kossak Jerzy & 91 & $1,261,000$ & 13,857 & 1886 & 1955 \\
\hline 9 & Malczewski Jacek & 71 & $9,401,300$ & 132,413 & 1854 & 1929 \\
\hline 10 & Nikifor Krynicki & 79 & 196,400 & 2,486 & 1895 & 1968 \\
\hline 11 & Nowosielski Jerzy & 81 & $5,706,700$ & 70,453 & 1923 & 2011 \\
\hline \multicolumn{2}{|c|}{ Sum } & 750 & $26,762,250$ & & & \\
\hline
\end{tabular}

Source: own elaboration.

The type and quality of the art piece is described by several variables such as: signature, technique and surface of the painting. A technique and materials characterize the type of work and this variable is specified as a number of dummies that indicate whether the art piece represents a certain type of work. The reference variant of the variable is: other techniques. Signature is one of the artworks attributes, it equals 1 if signature is visible. Surface $\left(\mathrm{cm}^{2}\right)$ of the artwork is the most commonly used variable that describes the physical characteristics of a painting. In general the parameters estimates for this variable should be positive however larger works may be difficult to display, thus in some models the squared surface is applied. In the model we use natural logarithms of the surface area.

The conditions of a transaction are represented by two variables: year and price relation. The year of sale is a set of binary variables definingthe year of transaction. The reference variant of this variable is Year_2010. Price relation between the reserve and the hammer price variable 
equals 1 if the former is bigger than the latter since in such a case the sale might not have taken place (so-called conditional sale).

\subsection{Hedonic regression}

In this paper we present ten models estimated OLS on the basis of the described above sample $(\mathrm{N}=750)$ regarding all selected artists, and - for comparison - two models of estimated employing subsamples of paintings produced by groups of 6 selected painters. The first subsample contains artworks whose authors keep positions from 1 to $6(\mathrm{~N}=363)$ in Table 2 , and from 6 to $11(\mathrm{~N}=468)$. In both models the reference variant of the artists variable remains Wyczółkowski.

The models' specification is presented in Table 3, where symbol "•" denotes variables present in the certain model. Models M10-M12 differ by the variants of the artist variable since they are estimated by employing different samples of paintings. The parameter estimates of selected models are presented in the Appendix in Tables A1-A4, and the basic parameters of the model properties - in Table A5.

Table 3. Comparison of models' specification

\begin{tabular}{|l|c|c|c|c|c|c|c|c|c|c|c|c|}
\hline \multicolumn{1}{|c|}{ Models } & M1 & M2 & M3 & M4 & M5 & M6 & M7 & M8 & M9 & M10 & M11 & M12 \\
\hline No. of observations & 750 & 750 & 750 & 750 & 750 & 750 & 750 & 750 & 750 & 750 & 468 & 343 \\
\hline Const & $\bullet$ & $\bullet$ & $\bullet$ & $\bullet$ & $\bullet$ & $\bullet$ & $\bullet$ & $\bullet$ & & $\bullet$ & $\bullet$ & $\bullet$ \\
\hline Year & $\bullet$ & $\bullet$ & $\bullet$ & $\bullet$ & $\bullet$ & $\bullet$ & $\bullet$ & $\bullet$ & $\bullet$ & $\bullet$ & $\bullet$ & $\bullet$ \\
\hline Auction house & $\bullet$ & $\bullet$ & $\bullet$ & $\bullet$ & $\bullet$ & $\bullet$ & $\bullet$ & $\bullet$ & $\bullet$ & $\bullet$ & $\bullet$ & $\bullet$ \\
\hline Artist & $\bullet$ & $\bullet$ & $\bullet$ & & & & $\bullet$ & $\bullet$ & $\bullet$ & $\bullet$ & $\bullet$ & $\bullet$ \\
\hline Signature & $\bullet$ & $\bullet$ & $\bullet$ & $\bullet$ & $\bullet$ & $\bullet$ & $\bullet$ & $\bullet$ & $\bullet$ & $\bullet$ & $\bullet$ & $\bullet$ \\
\hline Technique & $\bullet$ & $\bullet$ & $\bullet$ & $\bullet$ & $\bullet$ & $\bullet$ & $\bullet$ & $\bullet$ & $\bullet$ & $\bullet$ & $\bullet$ & $\bullet$ \\
\hline Price relation & $\bullet$ & $\bullet$ & & $\bullet$ & & $\bullet$ & $\bullet$ & & $\bullet$ & $\bullet$ & $\bullet$ & $\bullet$ \\
\hline Price class & $\bullet$ & & & $\bullet$ & $\bullet$ & $\bullet$ & & & & $\bullet$ & $\bullet$ & $\bullet$ \\
\hline Surface area & $\bullet$ & $\bullet$ & $\bullet$ & $\bullet$ & $\bullet$ & $\bullet$ & & & & $\bullet$ & $\bullet$ & $\bullet$ \\
\hline Surface area & & & & & & & $\bullet$ & $\bullet$ & $\bullet$ & & & \\
\hline Living status & $\bullet$ & & & $\bullet$ & $\bullet$ & $\bullet$ & & & $\bullet$ & & & \\
\hline Epoch & & & & & & $\bullet$ & & & & & & \\
\hline
\end{tabular}

Source: own elaboration.

The model M1 contains the whole set of variables (except epoch) and all variables, except signature, year and price relations, are significant. In comparison to M1, in the model M2 price class and artist's living status variables are missing while in M3 also price relations is omitted. We notice that although the models M2 and M3 have smaller adjusted $\mathrm{R}^{2}$, there is no autocorrelation in these models. Constructing the models M4 - M6 we reject the artist variable 
but we obtain the adjusted $\mathrm{R}^{2}$ comparable to M1. In the model M5 we additionally omit price relations that is insignificant in the majority of models, while we introduce the epoch variable to the model M6.

The models M7-M9 are characterized by the highest adjusted $\mathrm{R}^{2}$ although their specification is similar: M7 to M2, and M8 to M3, but the logarithm of surface area is replaced by its square. These two models also have the best properties from the point of view of the Akaike information criterion. The models M7 and M9 differ one from another by only by one variable (constant or living standard) while they have exactly the same parameter estimates.

An artist's living status is a significant variable with a positive sign. In all models containing the artists variable, signature is not significant, however in the models M4-M6 where the former variable is omitted, signature is significant with positive value of the parameter estimates, i.e. signed paintings obtain higher value. The name of a painter affects significantly and negatively the price of artwork in the case of all authors except Malczewski in the models M1-M3, and M10-M11 because Wyczółkowski’s paintings take the second place (after Malczewski) among the most expensive ones on average. Surface of the paintings influences positively and significantly the artwork's price while price relation is insignificant nearly in all models. All variants of the technique and materials used for the art piece production are significant in the presented models although not all of them in each model. While auction houses are significant in the majority of models, price class is always significant when it appears in the model while the year variable is usually insignificant.

\subsection{Hedonic art price indexes}

In our research we evaluate naive and hedonic price indexes. Parameter estimates of the models (3), presented in Tables A1-A4, are used to evaluate the hedonic quality adjustment (2), and, finally, the price index (1). At this stage of our research we must decide if we take in consideration all traded objects or if we remove artworks for which the hammer price was smaller than the reserve price, i.e. being the subject of conditional sale. In general, we assume that all artworks were sold regardless their price relation because of small number of objects in the sample and there are 162 cases of conditional sales. However we also calculate the naive and hedonic (for the model M7) indexes for the reduced samples of paintings, i.e. containing artworks which are undoubtedly sold i.e. for which price relation equals 1 .

It is also necessary to select the model which can be used for the hedonic quality adjustment calculation. In the paper we present indexes evaluated using parameter estimates of ten different models. In Table 4 art price indexes are presented, while Figures 1-4 contain the comparisons 
of percentage total in 2010 and average annual (5) returns. Naive indexes are denoted by NI and the number of artworks used for their calculation, for instance NI750 means that the index NI was calculated using 750 objects. Hedonic indexes we denote by $\mathrm{HI}$ and the symbol of a model, for instance HIM5 means that the index was calculated employing HQA evaluated on the basis of the model M5.

Table 4. Hedonic art price indexes

\begin{tabular}{|c|c|c|c|c|c|c|}
\hline Year & Model/sample & HQA & Price index & Model/sample & HQA & Price index \\
\hline 2008 & \multirow{3}{*}{\multicolumn{2}{|c|}{$\begin{array}{c}\text { NI750 } \\
\text { Naive index } \\
\text { Sample N =750 } \\
0.6163 \\
0.9441\end{array}$}} & 1.4984 & \multirow{3}{*}{\multicolumn{2}{|c|}{$\begin{array}{c}\text { NI588 } \\
\text { Naive index } \\
\text { Sample N = 588 } \\
0.5509 \\
0.8357\end{array}$}} & 1.4896 \\
\hline 2009 & & & & & & \\
\hline 2010 & & & & & & \\
\hline 2008 & \multirow{3}{*}{ HIM7 } & 1.1029 & 1.3586 & \multirow{3}{*}{ HIM7_588 } & 1.1142 & 1.3369 \\
\hline 2009 & & 0.6596 & 0.9344 & & 0.5849 & 0.9419 \\
\hline 2010 & & 1.1313 & 0.8345 & & 1.0640 & 0.7855 \\
\hline 2008 & \multirow{3}{*}{ HIM1 } & 1.4716 & 1.0182 & \multirow{3}{*}{\multicolumn{2}{|c|}{$\begin{array}{c}\text { NI468 } \\
\text { Naive index } \\
\text { Sample N =468 } \\
0.5271 \\
1.0972\end{array}$}} & 1.7773 \\
\hline 2009 & & 0.6150 & 1.0021 & & & \\
\hline 2010 & & 0.9607 & 0.9827 & & & \\
\hline 2008 & \multirow{3}{*}{ HIM2 } & 1.4137 & 1.0599 & \multirow{3}{*}{ HIM11 } & 0.9753 & 1.8222 \\
\hline 2009 & & 0.6867 & 0.8975 & & 0.9984 & 0.5279 \\
\hline 2010 & & 0.9860 & 0.9575 & & 0.9859 & 1.1128 \\
\hline 2008 & \multirow{3}{*}{ HIM3 } & 1.4160 & 1.0582 & \multirow{3}{*}{\multicolumn{2}{|c|}{$\begin{array}{c}\text { NI343 } \\
\text { Naive index } \\
\text { Sample N = 343 } \\
0.8473 \\
0.6478\end{array}$}} & 1.3059 \\
\hline 2009 & & 0.6862 & 0.8981 & & & \\
\hline 2010 & & 0.9887 & 0.9549 & & & \\
\hline 2008 & \multirow{3}{*}{ HIM4 } & 1.4607 & 1.0258 & \multirow{3}{*}{ HIM12 } & 1.2077 & 1.0813 \\
\hline 2009 & & 0.5934 & 1.0387 & & 0.8455 & 1.0021 \\
\hline 2010 & & 0.9643 & 0.9790 & & 0.9109 & 0.7111 \\
\hline 2008 & \multirow{3}{*}{ HIM5 } & 1.4575 & 1.0280 & & & \\
\hline 2009 & & 0.5930 & 1.0394 & & & \\
\hline 2010 & & 0.9821 & 0.9613 & \multicolumn{3}{|c|}{ Sample $N=750$} \\
\hline 2008 & \multirow{3}{*}{ HIM9 } & 1.3256 & 1.1303 & \multirow{3}{*}{ HIM10 } & 1.4732 & 1.0171 \\
\hline 2009 & & 0.8552 & 0.7206 & & 0.6087 & 1.0125 \\
\hline 2010 & & 0.9088 & 1.0389 & & 0.9705 & 0.9727 \\
\hline
\end{tabular}

Source: own elaboration.

As one can notice the values of indexes and even the tendency of price movements are connected with the model specification, and the sample selection. These differences are even more visible if we compare percentage returns from different indexes (Figure 1). Analyzing naive indexes calculated for 11 artists NI750, one can notice that in the years 2007-2010 prices 
of art were changing. For the whole sample the essential increase of art prices (nearly 50\%) is observed in 2008 in comparison to 2007, while in 2009 prices decreased by nearly $40 \%$ in comparison to the previous year, and they declined again in 2010 by $6 \%$. Thus as a result art prices dropped in 2010 in comparison to 2007 by 12.8\%. This decline is even bigger for the index NI588 - 31.4\% if all conditional sales are removed from the sample. Although the general tendency is similar in both samples (containing 750 or 588 objects), i.e. when comparing indexes NI750 and NI588.

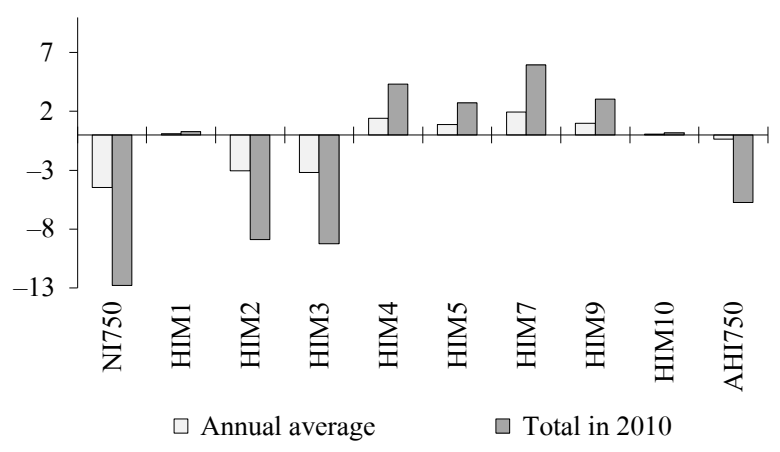

Fig. 1. Percentage returns from investments in art in the period 2007-2010 evaluated for the whole sample

Source: own elaboration.

Considering subsamples created by the artworks produced by 6 selected painters we notice essential differences in price tendency in both group of artists. The prices of paintings by J. Kossak, Hofman, Malczewski, Nikifor, Nowosielski and Wyczółkowski (NI468) increased by $78 \%$ in 2008 in comparison to 2007 , in the following year they dropped by $43 \%$, to increase in 2010 in comparison to the previous year by 10\% i.e. in 2010 prices were higher than in 2007 by $2.8 \%$. While the prices of artworks by W. Kossak, Chmieliński, Dwurnik, Erb, Dominik and Wyczółkowski (NI343) increased by 31\% in 2008 in comparison to basic year, in the following year they decreased by $15 \%$ in comparison to 2008, and decreased in 2010 in comparison to the previous year by 35\% i.e. in 2010 prices were lower than in 2007 by $28.3 \%$. Figures 2 and 3 illustrate differences of returns evaluated for the naive (NI750, NI468 and NI343) and hedonic indexes (HIM10, HIM11 and HIM12), generated from the models M10-M12, which have the same set of variables (but different variants of the artist variable) and were estimated for the samples containing 750, 468 and 343 elements, respectively. We also compare returns from the 
indexes evaluated for the sample containing all variables (i.e. indexes NI750 and HIM7) and the sample without the conditional sale objects (-NI588 and HIM7_588).

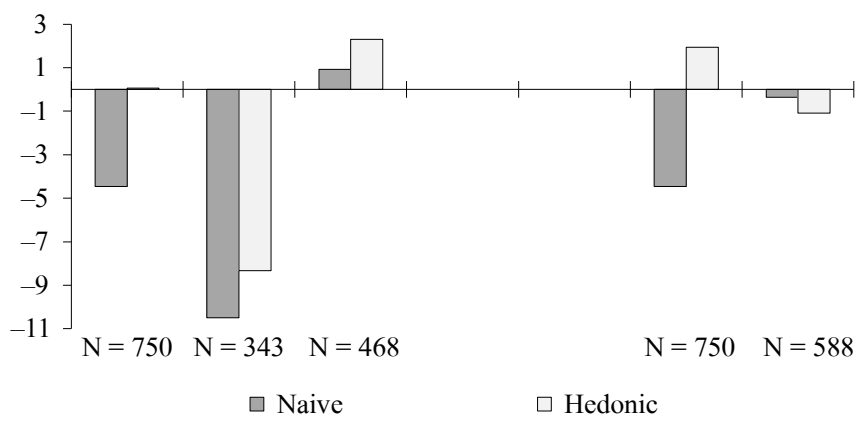

Fig. 2. Percentage annual average returns from indexes evaluated for the whole and limited samples

Source: own elaboration.

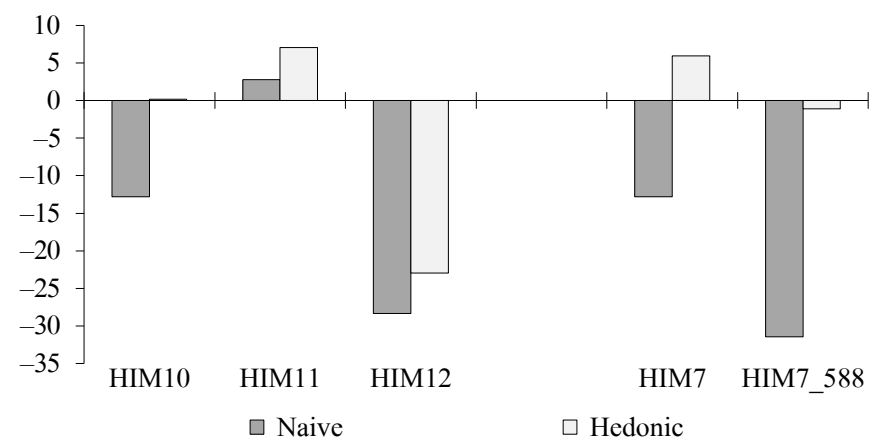

Fig. 3. Percentage total returns from indexes evaluated for the whole and limited samples Source: own elaboration.

The hedonic quality adjustment essentially affects price indexes. HQA evaluated on the basis of the models M2, M3, M7 for both samples, and M11 do not change the general direction of price movements represented by the naive indexes, while for other models such changes are visible.

The HIM11 indexes show that prices increased by $82 \%$ in 2008 in comparison to 2007 , in 2009 they dropped by $43 \%$, to increase in 2010 in comparison to the previous year by $11 \%$, i.e. in 2010 prices were higher than in 2007 by $7 \%$. The general tendency of price changes was 
the same, although the naive index showed increase of prices only by $3 \%$. The price indexes estimated for the second subsample HIM12 inform that prices increased by $8 \%$ in 2008 in comparison to the basic year, then they stabilized at the level of 2008, and decreased in 2010 in comparison to the previous year by $29 \%$, i.e. in 2010 prices were lower than in 2007 by $22.9 \%$. In this case the price change in 2010 in comparison to 2007 pursued the same direction for the hedonic and the naive index although the tendency of price changes described by both indexes is different. In other words the specification of the hedonic model together with the estimation sample influence the hedonic price index.

Table 5. Comparison of naïve and aggregated indexes

\begin{tabular}{|c|c|c|c|c|}
\hline \multirow{2}{*}{ Year } & \multicolumn{4}{|c|}{ Indexes } \\
\cline { 2 - 5 } & Naive & Hedonic & Naive & Hedonic \\
\cline { 2 - 5 } & NI750 & AHI750 & NI468 & AHIM10_12 \\
\hline 2008 & 1.4984 & 1.1039 & 1.7773 & 1.2608 \\
2009 & 0.6163 & 0.9573 & 0.5271 & 0.8122 \\
2010 & 0.9441 & 0.9427 & 1.0972 & 0.9165 \\
\hline & NI588 & AHIM7 & NI343 & AHIM11_12 \\
\hline 2008 & 1.4896 & 1.3477 & 1.3059 & 1.4037 \\
2009 & 0.5509 & 0.9381 & 0.8473 & 0.7273 \\
2010 & 0.8357 & 0.8096 & 0.6478 & 0.8896 \\
\hline
\end{tabular}

Source: own elaboration.

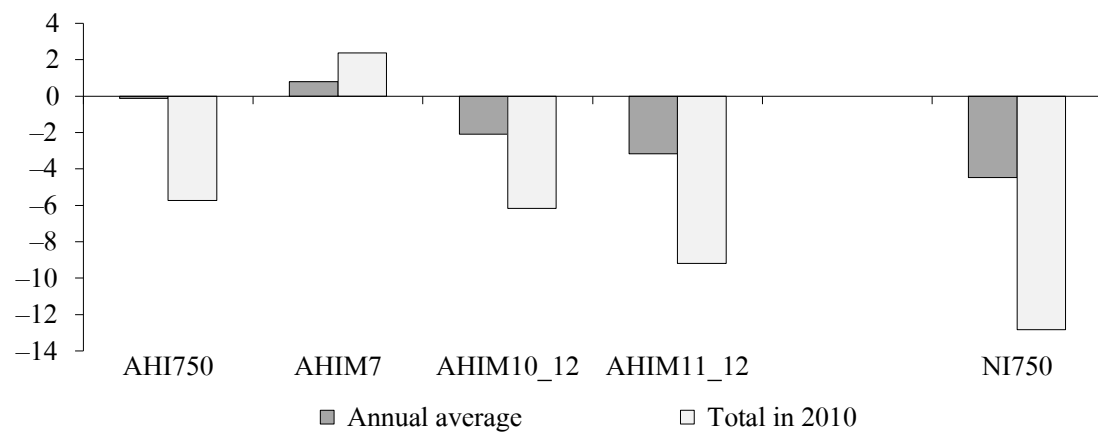

Fig. 4. Percentage returns from investments in art evaluated for the aggregated indexes Source: own elaboration.

Therefore the aggregated indexes (4) are evaluated from all indexes calculated for: (a) the whole sample - it is denoted as AHI750, (b) for the model M7 estimated for the samples $\mathrm{N}=750$ and $\mathrm{N}=588$ that we denote by AHM7, (c) for the models M10-M12, and the index 
is denoted as AHIM10_12, and (d) the models M11-M12 i.e. AHIM11_12. In Table 5 we compare the aggregated to the naive indexes and Figure 4 contains returns from the aggregated indexes. As one can notice the aggregated indexes are not influenced by the specification of the single model specification, so the returns keep the same tendency as the naive indexes with the exception of AHIM7.

\section{Conclusions}

The major problem to consider art as investment instrument is the lack of a systematic measure of its financial performance. Due to its heterogeneity (each piece is different) and its infrequency of trading (the exact same piece does not come to the market very often), the determination of changes in market value is difficult to ascertain. To construct an art price index we apply the hedonic regression method, employing data from auctions that were held in Poland in 2007-2008. Because of a great variety of works traded we select the sample of paintings produced by 11 the "most liquid" Polish artists. We do not claim that the basket constructed in such a way represents the whole paintings market in Poland but it describes tendencies for well-known Polish painters ${ }^{31}$.

The results of our investigation show that the hedonic quality adjustment affects the price index but we do not know the criteria that should be applied in the procedure of the model selection. It is difficult to evaluate the quality of models by parameter estimates interpretation since the majority of variables represent qualitative features. The level of the artworks' price description is very high, i.e. the adjusted $\mathrm{R}^{2}$ varies from 0.81 (models: $\mathrm{M} 2$ and M3) to 0.995 (models: M7-M9). Due to Akaike information criteria the best models are M7-M9. The hypothesis about the lack of the random coefficient autocorrelation was not rejected only for 3 models: M2, M3 and M10.

Therefore we proposed an aggregated hedonic index which is less sensitive to the specification of the single model. Comparing situation on art market, one may notice that the decline of art prices became visible in 2009, while the main index of the Warsaw Stock Exchange $^{32}-$ WIG decreased by $51 \%$ (in 2008 in comparison to the previous year). As a result of the financial crisis in 2010 the decline of WIG was by 15\% in comparison to the year 2007. In that period the decrease of art prices was $12.8 \%$ for the naive index NI750, and $5.7 \%$ according to the aggregated hedonic index AHI750. Therefore, also in Poland investment in art seems to be a comparatively safe ${ }^{33}$ asset class that can serve as a hedging instrument against inflation and 
create the possibility to diverse the investment portfolio since art is not correlated with equities or bonds but associated with tangible assets such as gold or commodities.

\section{Acknowledgements}

Investing in Paintings on the Financial Market, research conducted under the National Science Centre Grant No. 2012/05/B/HS4/04188.

\section{Appendix}

Table A1. Estimated models

\begin{tabular}{|c|c|c|c|c|c|c|}
\hline Variables & Estimates & M1 & Estimates & M2 & Estimates & M3 \\
\hline 1 & 2 & 3 & 4 & 5 & 6 & 7 \\
\hline const & 5.6804 & $* * *$ & 2.7877 & $* * *$ & 2.7934 & $* * *$ \\
\hline YEAR_2007 & 0.0075 & & 0.0934 & & 0.0971 & \\
\hline YEAR_2008 & 0.0231 & & 0.0758 & $* *$ & 0.0768 & $* *$ \\
\hline YEAR_2009 & 0.0374 & & 0.0145 & & 0.0154 & \\
\hline AGRAART & -0.1599 & $* *$ & 0.2945 & $* *$ & 0.2989 & $* *$ \\
\hline Agra-Art & -0.1151 & & 0.1990 & & 0.2013 & \\
\hline Desa & -0.1211 & & 0.4084 & $* * *$ & 0.4026 & $* * *$ \\
\hline Desa Unicum & -0.2795 & $* * *$ & 0.4798 & $* * *$ & 0.4816 & $* * *$ \\
\hline Okna Sztuki & -0.1904 & $* *$ & 0.0998 & & 0.1032 & \\
\hline Ostoya & 0.0460 & & 0.8052 & $* * *$ & 0.7968 & $* * *$ \\
\hline Polswiss Art & -0.2252 & $* * *$ & 0.0895 & & 0.0807 & \\
\hline Rempex & -0.2733 & $* * *$ & 0.0172 & & 0.0080 & \\
\hline Kossak_J & -0.5372 & $* * *$ & -1.5906 & $* * *$ & -1.5896 & $* * *$ \\
\hline Kossak_W & -0.3312 & $* * *$ & -0.8769 & $* * *$ & -0.8780 & $* * *$ \\
\hline Chmieliski & -0.4340 & $* * *$ & -1.2274 & $* * *$ & -1.2266 & $* * *$ \\
\hline Dwurnik & -0.9170 & $* * *$ & -2.2824 & $* * *$ & -2.2810 & $* * *$ \\
\hline Erb & -0.3546 & $* * *$ & -1.0908 & $* * *$ & -1.0864 & $* * *$ \\
\hline Hofman & -0.3503 & $* * *$ & -1.0883 & $* * *$ & -1.0862 & $* * *$ \\
\hline Malczewski & 0.1506 & $* *$ & 0.3115 & $* * *$ & 0.3125 & $* * *$ \\
\hline Nikifor & -0.4730 & $* * *$ & -1.3326 & $* * *$ & -1.3319 & $* * *$ \\
\hline Nowosielski & -0.1383 & $* *$ & -0.1185 & & -0.1186 & \\
\hline Dominik & -0.7095 & $* * *$ & -1.9053 & $* * *$ & -1.9050 & $* * *$ \\
\hline signature & 0.0641 & & -0.0435 & & -0.0457 & \\
\hline watercolour & 0.2566 & $* * *$ & 0.1968 & & 0.1991 & \\
\hline acrylic & 0.2798 & $* *$ & 0.6975 & $* * *$ & 0.6998 & $* * *$ \\
\hline gouache & 0.2364 & $* *$ & 0.2849 & & 0.2918 & \\
\hline oil & 0.3449 & $* * *$ & 0.8856 & $* * *$ & 0.8869 & $* * *$ \\
\hline pencil & 0.0414 & & -0.2460 & & -0.2453 & \\
\hline
\end{tabular}




\begin{tabular}{|l|c|c|c|c|c|c|}
\hline \multicolumn{1}{|c|}{1} & 2 & 3 & 4 & 5 & 6 & 7 \\
\hline pastel & 0.2363 & $* *$ & 0.4502 & $* *$ & 0.4525 & $* *$ \\
\hline tempera & 0.4014 & $* * *$ & 0.6350 & $* * *$ & 0.6377 & $* * *$ \\
\hline drawing ink & -0.1522 & & -0.5984 & $* *$ & -0.5986 & $* *$ \\
\hline price relation & -0.0404 & & -0.0273 & & & \\
\hline CLASS_1 & 2.9213 & $* * *$ & & & & \\
\hline CLASS_2 & 1.5779 & $* * *$ & & & & \\
\hline CLASS_3 & 0.84983 & $* * *$ & & & & \\
\hline surface area & 0.2326 & $* * *$ & 0.5646 & $* * *$ & 0.5636 & $* * *$ \\
\hline artist's living status & 0.1265 & $* *$ & & & & \\
\hline
\end{tabular}

Source: own elaboration.

Table A2. Estimated models

\begin{tabular}{|c|c|c|c|c|c|c|}
\hline Variables & Estimates & M4 & Estimates & M5 & Estimates & M6 \\
\hline const & 6.3626 & $* * *$ & 5.5577 & $* * *$ & 5.4910 & $* * *$ \\
\hline YEAR_2007 & -0.0343 & & -0.0206 & & -0.0279 & \\
\hline YEAR_2008 & -0.0034 & & 0.0035 & & 0.0017 & \\
\hline YEAR_2009 & 0.0185 & & 0.0136 & & 0.0119 & \\
\hline Agra-Art & -0.1679 & $* *$ & -0.2437 & $* * *$ & -0.2415 & $* * *$ \\
\hline Desa & -0.1112 & & -0.1822 & $* *$ & -0.1996 & $* *$ \\
\hline Desa Unicum & -0.1148 & & -0.1989 & $* *$ & -0.1947 & $* *$ \\
\hline Okna Sztuki & -0.3267 & $* * *$ & -0.3944 & $* * *$ & -0.4000 & $* * *$ \\
\hline Ostoya & -0.2513 & $* * *$ & -0.3061 & $* * *$ & -0.3026 & $* * *$ \\
\hline Polswiss Art & -0.0130 & & -0.0976 & & -0.0805 & \\
\hline Rempex & -0.2337 & $* * *$ & -0.3160 & $* * *$ & -0.3127 & $* * *$ \\
\hline Rynek Sztuki & -0.2915 & $* * *$ & -0.3719 & $* * *$ & -0.3677 & $* * *$ \\
\hline signature & 0.1474 & $* * *$ & 0.1615 & $* * *$ & 0.1605 & $* * *$ \\
\hline watercolour & 0.0436 & & 0.0809 & & 0.0831 & \\
\hline acrylic & 0.0090 & & 0.0926 & & 0.0951 & \\
\hline gouache & 0.0645 & & 0.1046 & & 0.0967 & \\
\hline oil & 0.0955 & & 0.1167 & & 0.1125 & \\
\hline pencil & 0.1458 & & 0.0733 & & 0.1006 & \\
\hline pastel & 0.1968 & & 0.2292 & $*$ & 0.2102 & $*$ \\
\hline tempera & 0.2989 & $* *$ & 0.2512 & $*$ & 0.2794 & $* *$ \\
\hline drawing ink & 0.0238 & & -0.0792 & & -0.0586 & \\
\hline surface area & 0.1343 & $* * *$ & 0.1945 & $* * *$ & 0.2011 & $* * *$ \\
\hline price relation & -0.0361 & & & & -0.0382 & \\
\hline CLASS_1 & 3.7026 & $* * *$ & 3.5083 & $* * *$ & 3.5223 & $* * *$ \\
\hline CLASS_2 & 1.9900 & $* * *$ & 1.8907 & $* * *$ & 1.8925 & $* * *$ \\
\hline CLASS_3 & 1.0717 & $* * *$ & 1.0170 & $* * *$ & 1.0184 & $* * *$ \\
\hline artist's living status & 0.1905 & $* * *$ & 0.3879 & $* * *$ & 0.3442 & $* * *$ \\
\hline epoch & & & & & 0.058 & \\
\hline
\end{tabular}

Source: own elaboration. 
Table A3. Estimated models

\begin{tabular}{|c|c|c|c|c|c|c|}
\hline Variables & Estimates & M7 & Estimates & M8 & Estimates & M9 \\
\hline const & 5.0405 & $* * *$ & 5.0400 & $* * *$ & & \\
\hline YEAR_2007 & 0.0067 & & 0.0075 & & 0.0067 & \\
\hline YEAR_2008 & 0.0007 & & 0.0010 & & 0.0007 & \\
\hline YEAR_2009 & 0.0019 & & 0.0021 & & 0.0019 & \\
\hline Agra-Art & 0.0834 & $* *$ & 0.0843 & $* * *$ & 0.0834 & $* *$ \\
\hline Desa & 0.0844 & & 0.0848 & $* * *$ & 0.0844 & \\
\hline Desa Unicum & 0.0550 & $* * *$ & 0.0536 & $* *$ & 0.0550 & $* * *$ \\
\hline Okna Sztuki & 0.0701 & $* *$ & 0.0707 & $* *$ & 0.0701 & $* *$ \\
\hline Ostoya & 0.0642 & $* * *$ & 0.0649 & $* * *$ & 0.0642 & $* * *$ \\
\hline Polswiss Art & 0.0717 & $* * *$ & 0.0697 & $* * *$ & 0.0717 & $* * *$ \\
\hline Rempex & 0.0606 & $* * *$ & 0.0584 & $* * *$ & 0.0606 & $* * *$ \\
\hline Rynek Sztuki & 0.0504 & $* *$ & 0.0481 & $* *$ & 0.0504 & $* *$ \\
\hline Kossak_J & -0.0566 & $* * *$ & -0.0565 & $* * *$ & -0.0566 & $* * *$ \\
\hline Kossak_W & -0.0318 & & -0.0321 & $*$ & -0.0318 & \\
\hline Chmieliski & -0.0601 & $* * *$ & -0.0600 & $* * *$ & -0.0601 & $* * *$ \\
\hline Dwurnik & -0.1413 & $* * *$ & -0.1413 & $* * *$ & -0.1413 & $* * *$ \\
\hline Erb & -0.0420 & $* *$ & -0.0409 & $* *$ & -0.0420 & $* *$ \\
\hline Hofman & -0.0484 & $* *$ & -0.0479 & $* *$ & -0.0484 & $* *$ \\
\hline Malczewski & -0.1007 & $* * *$ & -0.1003 & $* * *$ & -0.1007 & $* * *$ \\
\hline Nikifor & -0.2556 & $* * *$ & -0.2553 & $* * *$ & -0.2556 & $* * *$ \\
\hline Nowosielski & -0.0471 & $* * *$ & -0.0471 & $* * *$ & -0.0471 & $* * *$ \\
\hline Dominik & -0.0594 & $* * *$ & -0.0596 & $* * *$ & -0.0594 & $* * *$ \\
\hline signature & -0.0038 & & -0.0043 & & -0.0038 & \\
\hline watercolour & -0.0155 & & -0.0149 & & -0.0155 & \\
\hline acrylic & 0.0448 & & 0.0452 & & 0.0448 & \\
\hline gouache & -0.0038 & & -0.0021 & & -0.0038 & \\
\hline oil & 0.0561 & $* *$ & 0.0563 & $* *$ & 0.0561 & $* *$ \\
\hline pencil & -0.0704 & $* *$ & -0.0701 & $* *$ & -0.0704 & $* *$ \\
\hline pastel & 0.0336 & & 0.0341 & & 0.0336 & \\
\hline tempera & 0.0296 & & 0.0303 & & 0.0296 & \\
\hline drawing ink & -0.0171 & & -0.0172 & & -0.0171 & \\
\hline surface area ${ }^{2}$ & 0.0484 & $* * *$ & 0.0484 & $* * *$ & 0.0484 & $* * *$ \\
\hline price relation & -0.0065 & & & & -0.0065 & \\
\hline artist's living status & & & & & 5.0405 & $* * *$ \\
\hline
\end{tabular}

Source: own elaboration.

Table A4. Estimated models

\begin{tabular}{|l|c|c|c|c|c|c|}
\hline \multicolumn{1}{|c|}{ Variables } & Estimates & M10 & Estimates & M11 & Estimates & M12 \\
\hline \multicolumn{1}{|c|}{1} & 2 & 3 & 4 & 5 & 6 & 7 \\
\hline const & 5.8257 & $* * *$ & 5.4660 & $* * *$ & 6.1098 & $* * *$ \\
\hline YEAR_2007 & -0.0018 & & 0.0056 & & -0.0035 & \\
\hline YEAR_2008 & 0.0076 & & 0.0094 & & 0.0557 & \\
\hline YEAR_2009 & 0.0092 & & 0.0056 & & 0.1109 & $* *$ \\
\hline Agra-Art & -0.1674 & $* *$ & -0.0071 & & -0.2185 & $* *$ \\
\hline Desa & -0.1283 & & 0.0270 & & -0.1298 & \\
\hline Desa Unicum & -0.1292 & & 0.0542 & & -0.1380 & \\
\hline
\end{tabular}




\begin{tabular}{|c|c|c|c|c|c|c|}
\hline 1 & 2 & 3 & 4 & 5 & 6 & 7 \\
\hline Okna Sztuki & -0.2576 & $* *$ & -0.0810 & & -0.2288 & \\
\hline Ostoya & -0.2022 & $* *$ & -0.0834 & & -0.1399 & \\
\hline Polswiss Art & 0.0409 & & 0.2274 & & 0.0050 & \\
\hline Rempex & -0.2318 & $* * *$ & -0.0963 & & -0.1984 & $* *$ \\
\hline Rynek Sztuki & -0.2749 & $* * *$ & -0.1318 & & -0.3101 & $* * *$ \\
\hline Kossak_W & -0.3254 & $* * *$ & & & -0.3183 & $* * *$ \\
\hline Chmieliski & -0.4334 & $* * *$ & & & -0.4971 & $* * *$ \\
\hline Dwurnik & -0.9172 & $* * *$ & & & -1.0535 & $* * *$ \\
\hline Erb & -0.3498 & $* * *$ & & & -0.4167 & $* * *$ \\
\hline Dominik & -0.7115 & $* * *$ & & & -0.7609 & $* * *$ \\
\hline Kossak_J & -0.5352 & $* * *$ & -0.5161 & $* * *$ & & \\
\hline Hofman & -0.3498 & $* * *$ & -0.3665 & $* * *$ & & \\
\hline Malczewski & 0.1490 & $* *$ & 0.1455 & $* *$ & & \\
\hline Nikifor & -0.4698 & $* * *$ & -0.3381 & $* * *$ & & \\
\hline Nowosielski & -0.1412 & $* *$ & -0.1473 & * & & \\
\hline signature & 0.0654 & & 0.13103 & * & -0.0812 & \\
\hline watercolour & 0.1709 & $*$ & 0.17205 & $*$ & 0.06323 & \\
\hline acrylic & 0.2835 & $* *$ & 0.0589 & & 0.29661 & $* *$ \\
\hline gouache & 0.2014 & $*$ & 0.2086 & $*$ & 0.2823 & $*$ \\
\hline oil & 0.3514 & $* * *$ & 0.3988 & $* * *$ & 0.3046 & $* * *$ \\
\hline pencil & 0.0522 & & 0.1554 & & 0.0653 & \\
\hline pastel & 0.2423 & $* *$ & 0.2210 & $*$ & 0.2615 & $* *$ \\
\hline tempera & 0.4088 & $* * *$ & 0.4374 & $* * *$ & 0.5683 & $* *$ \\
\hline drawing ink & -0.1408 & & -0.0236 & & -0.3546 & $*$ \\
\hline price relation & -0.0391 & & 0.0022 & & -0.1647 & $* * *$ \\
\hline CLASS_1 & 2.9247 & $* * *$ & 2.9439 & $* * *$ & 2.7765 & $* * *$ \\
\hline CLASS_2 & 1.5806 & $* * *$ & 1.6527 & $* * *$ & 1.4380 & $* * *$ \\
\hline CLASS_3 & 0.8497 & $* * *$ & 0.8131 & $* * *$ & 0.8346 & $* * *$ \\
\hline surface area & 0.2314 & $* * *$ & 0.2383 & $* * *$ & 0.2327 & $* * *$ \\
\hline
\end{tabular}

Source: own elaboration.

Table A5. Comparison of models' properties

\begin{tabular}{|l|c|c|c|c|c|c|}
\hline \multicolumn{1}{|c|}{ Model } & $\mathrm{R}^{2}$ adj. & $\mathrm{F}$ & $\begin{array}{c}\text { Degrees } \\
\text { of freedom }\end{array}$ & Akaike & rho1 & D-W \\
\hline M1 & 0.9342 & 296.40 & $(36 ; 713)$ & 482.96 & 0.0855 & 1.8206 \\
\hline M2 & 0.8114 & 101.68 & $(32 ; 717)$ & 1269.1 & 0.0330 & 1.9311 \\
\hline M3 & 0.8115 & 105.07 & $(31 ; 718)$ & 1267.3 & 0.0306 & 1.9359 \\
\hline M4 & 0.9165 & 317.30 & $(26 ; 723)$ & 651.88 & 0.1340 & 1.7314 \\
\hline M5 & 0.9207 & 335.58 & $(25 ; 724)$ & 613.17 & 0.1482 & 1.7032 \\
\hline M6 & 0.9209 & 312.25 & $(27.722)$ & 613.83 & 0.1412 & 1.7171 \\
\hline M7 & 0.9953 & 4910.11 & $(32 ; 717)$ & -1492.91 & 0.2588 & 1.4808 \\
\hline M8 & 0.9953 & 5071.98 & $(31 ; 718)$ & -1494.38 & 0.2600 & 1.4780 \\
\hline M9 & 0.9953 & 4910.11 & $(32 ; 717)$ & -1492.91 & 0.2588 & 1.4808 \\
\hline M10 & 0.9338 & 374.30 & $(35 ; 714)$ & 486.07 & 0.0348 & 1.9284 \\
\hline M11 & 0.9423 & 255.41 & $(30 ; 437)$ & 355.26 & 0.0054 & 1.9879 \\
\hline M12 & 0.9068 & 113.78 & $(30 ; 312)$ & 192.37 & 0.0761 & 1.8401 \\
\hline
\end{tabular}

Source: own elaboration. 


\section{Notes}

${ }^{1}$ Ginsburgh et al. (2006), p. 947.

${ }^{2}$ For example: Anderson (1974); Frey, Pommerehne (1988),(1989a); Pesando (1993); Mei, Moses (2002); Worthington, Higgs (2003), (2004); Campbell (2004), (2008); Adamowska (2008); Higgs (2012); Hsieh, et al. (2010); Kraeussl, Wiehenkamp (2012); Sokołowska (2012); Frey, Cueni (2013).

${ }^{3}$ Goetzmann et al. (2011).

${ }^{4}$ Frey, Cueni (2013).

${ }^{5}$ See Frey, Pommerehne (1989b) describing the story of the painting "Daniel in the Lion's Den".

${ }^{6}$ Renneboog and Spaenjers (2013) report 220 "fallen from fashions" artists who were included in the 1926, 1959 and 1980 edition of Gardner's Art through the Ages, but not in the 1996 or 2004 edition. (Gardner's Art Through the Ages is an American textbook on art history that was written by H. Gardner (1878-1946) and published for the first time in 1926. Co-authors of the 2004 edition are F.S. Kleiner and Ch.J. Mamiya).

${ }^{7}$ Goetzmann et al. (2011) present the evidence that personal income of the highest earners determines price of art - one percent fall in income of the earners in the top 0.1 percent income distribution in the UK triggers a decline in art prices of nearly 10 percent.

${ }^{8}$ Ashenfelter, Graddy (2006); Ginsburgh et al. (2006).

${ }^{9}$ For example, Pesando (1993), Pesando, Shum (1999), Mei, Moses (2002) - employ repeat sales; Mok et al. (1993), Landes (2000) - geometric repeat sales; Ginsburgh, Schwed (1992), Kraussl, van Elsland (2008), Higgs, Warthington (2005) - hedonic index; Candela et al. (2004) - quality adjusted price; Renneboog, van Houtte (2002) - basket index.

${ }^{10}$ Ginsburgh et al. (2006).

11 Candela et al. (1997).

${ }^{12}$ Locatelli-Biey, Zanola (2002) - consider sculptures; Pesando (1993) - prints; Candela et al. (2004) - paintings; Ginsburgh, Schwed (1992) - drawings, etc.

13 As it is done by Landes (2000) who takes Ganz collection.

${ }^{14}$ For instant, Pesando (1993) - concerns modern prints and Picasso prints; Candela et al. (2004) - modern and contemporary, 19th century, Old Master paintings; Ginsburgh, Schwed (1992) - Flemish-Dutch, French, Italian Old Master drawings.

${ }^{15}$ For example, Pesando, Shum (1999) analyzed Picasso prints only.

${ }^{16}$ Mok et al. (1993) consider modern Chinese paintings, a Kraussl, van Elsland (2008) - German paintings in general; Higgs, Warthington (2005) - Australian paintings.

${ }^{17}$ Neiheim (2006).

${ }_{18}$ Hedonic price indexes are discussed by Nesheim (2006), Triplett (2006) while their application on the art market by Candela, et al. (2004), Kraeussl, van Elsland (2008), Kraeussl, Wiehenkamp (2012) to mention some research provided for developed art markets. However the first attempt to construct hedonic art price indexes for emerging markets was made by Kraeuss, Logher (2008) who consider art markets in China, Russia and India.

19 Renneboog, Van Houtte (2002).

${ }^{20}$ See Widłak (2010) who presents different forms of the hedonic price index.

${ }^{21}$ Ginsburrgh et al. (2006).

${ }^{22}$ World Wealth Report (2012), Capgemini i RBC Wealth Management.

${ }^{23}$ Deloitte (2013).

${ }^{24}$ Mc Andrew (2013).

${ }^{25}$ Gajewski \& Potocki (2013), pp. 18-19.

${ }^{26}$ Ibidem, p. 13.

${ }^{27}$ Deloitte (2013).

28 See Gajewski, Potocki (2013).

${ }^{29}$ The basic data base from auctions of paintings held by 41 auction houses and foundations in Poland was constructed by Lucińska (2012).

${ }^{30}$ In the paper Kompa and Witkowska (2013) sample selection provided due to different criteria is discussed. 
${ }^{31}$ Similar approach was made by Higgs, Worthington (2005) who consider 60 "well-known" Australian artists.

${ }^{32}$ Data from www.gpw.pl/analizy_i_statystyki_pelna_wersja.

${ }^{33}$ Renneboog and Spaenjers (2013) on the basis on more than a million auction trades, that took place in the period 1900-2007, for 10,100 artists show that return for art is only $4 \%$ per year while stocks yield a return over $6.5 \%$ but art investment is more profitable than government bonds and gold, which yield returns $2-3 \%$, and comparable to corporate bonds that gave also $4 \%$ average annual return. However risk measured by standard deviation is the highest for gold (more than $24 \%$ ), than for art (10\%), equities (16.5\%), government bonds (less than $11 \%$ ) and corporate bonds $(9.5 \%)$.

\section{References}

Adamowska, W. (2008). Is Art Such a Good Investment? Investing in Fine Art on the International and Polish Action Market. Unpublished Master thesis written under the supervision of F. Vermeylen, Erasmus University, Rotterdam.

Anderson, R.C. (1974). Paintings as an Investment. Economic Inquiry, 12 (1), 13-26.

Ashenfelter, O. \& Graddy, K. (2006). Art Auctions. In: Eds. V. Ginsburgh \& D. Throsby. Handbook of the Economics of Arts and Culture (pp. 909-945). Amsterdam, North Holland: Elsevier.

Campbell, R.A.J. (2004). The Art of Portfolio Diversification. LIFE working paper, No. 04009, Maastricht University. Retrieved May 19, 2011, from www.google.pl/url?sa=t\&rc $\mathrm{t}=\mathrm{j} \& \mathrm{q}=\&$ esrc $=\mathrm{s} \&$ source $=$ web $\& \mathrm{~cd}=2 \& \mathrm{ved}=0 \mathrm{CCoQFjAB} \&$ url $=\mathrm{http} \% 3 \mathrm{~A} \% 2 \mathrm{~F} \% 2 \mathrm{Fweb}$. econ.ku.dk\%2Ffru $\% 2$ Fconference $\% 2 F$ Programme $\% 2$ FSaturday $\% 2 F D 4 \% 2 F C a m p b e$ 11_Art\%2520InvestmentCampbell.pdf\&ei=K7ShVJPuJ5PU7Ab8xYHwDg\&usg=AFQjC NGVAT2ofx_F0N76v2nGuDg8bA18tw\&sig2=CexJGPxmHTwxqWOmMRNaCg\&bvm $=$ bv.82001339,d.ZGU.

Campbell, R.A.J. (2008). Art as a Financial Investment. The Journal of Alternative Investments, 10 (4), 64-81. DOI: 10.3905/jai.2008.705533.

Candela, G., \& Scorcu, A.E. (1997). A Price index for Art Market Auctions. An Application to the Italian Market of Modern and Contemporary Oil Paintings. Journal of Cultural Economics, 21 (3), 175-196.

Candela, G., Figini, P. \& Scorcu, A.E. (2004). Price Indices for Artists - A Proposal. Journal of Cultural Economics, 28 (4), 285-302.

Deloitte, (2013). Rynek sztuki. Sztuka rynku, www.deloitte.com/assets/DcomPoland/Local\%20 Assets/Documents/Raporty,\%20badania,\%20rankingi/p1_Art\&Banking_PL.pdf (12.11.2013).

Frey, B.S. \& Cueni R. (2013). Why Invest in Art? The Economist's Voice, 10 (1), 1-6. DOI: $10.1515 / \mathrm{ev}-2013-0014$. 
Frey, B.S. \& Pommerehne, W.W. (1988). Is Art Such a Good Investment? The Public Interest, 91, 79-86, www.nationalaffairs.com/public_interest/detail/is-art-such-a-good-investment.

Frey, B.S. \& Pommerehne, W.W. (1989a). Art Investment: An Empirical Inquiry. Southern Economic Journal, 56 (2), 396-409, www.jstor.org/stable/1059218.

Frey, B.S. \& Pommerehne, W.W. (1989b). Muses and Markets. Explorations in the Econo-mics of the Arts. Cambridge, MA: Basil Blackwell.

Gajewski, M. \& Potocki, T. (2013). Skate's Focus: Poland's Art Market The Rising Star of Central Europe. Report created by Skate's Art Market Research Art \& Business Magazine SA, Skate's, LLC, New York, NY, USA. Retrieved from skatesart.files.wordpress. com/2013/03/skates-focus-polands-art-market.pdf (29.01.2014).

Ginsburgh, V., Mei, J. \& Moses, M. (2006). The Computation of Prices Indices. In: Eds. V. Ginsburgh, D. Throsby. Handbook of the Economics of Art and Culture (Vol. 1, chap. 27, pp. 947-979).

Ginsburgh, V. \& Schwed, N. (1992). Price Trends for Old Masters' Drawings: 1980-1991. The Art Newspaper, September 1992, https:/dipot.ulb.ac.be/dspace/bitstream/2013/99302/1/77. drawings.pdf (5.01.2014).

Goetzmann, W.N., Renneboog, L. \& Spaenjers, C. (2011). Art and Money. American Economic Review, 101 (3), 222-226. DOI: 10.1257/aer.101.3.222.

Higgs, H. (2012). Australian Art Market Prices during the Global Financial Crisis and two Earlier Decades. Australian Economic Papers, 51 (4), 189-209. DOI: 10.1111/14678454.12001.

Higgs, H. \& Worthington, A. (2005). Financial Returns and Price Determinants in the Australian Art Market: 1973-2003. Economic Record, 81 (253), 113-123.

Hsieh, S., Lee, J. \& Tzeng, L.Y. (2010). Art as an Investment: Empirical Study of Asian Contemporary and Chinese 20th Century Modern Art. International Conference on Finance Department of Finance, National Taiwan University, December 10-11, 2010, www.fin. ntu.edu.tw/ conference/conference 2010/proceedings/proceeding/11/11-1(A40).pdf (27.12.2012).

Kompa, K. \& Witkowska, D. (2013). Indeks rynku sztuki. Badania pilotażowe dla wybranych malarzy polskich. Zarządzanie i Finanse, 11 (3/2), 33-50. Prace i Materiały Wydziału Zarządzania Uniwersytetu Gdańskiego.

Kraeussl, R. \& van Elsland, N. (2008). Constructing the True Art Market Index - A Novel 2-Step Hedonic Approach and its Application to the German Art Market. CFS working paper, No. 2008/11, Center for Financial Studies Frankfurt University.

Kraeussl, R. \& Logher, R. (2010). Emerging Art Markets. Emerging Markets Review, 11 (4), 301-318. DOI: 10.1016/j.ememar.2010.07.002. 
Kraeussl, R. \& Wiehenkamp, Ch. (2012). A call on Art investments. Review of Derivatives Research, 15 (1), 1-23. DOI:10.1007/s11147-011-9061-x.

Landes, W.M. (2000). Winning the Art Lottery: The Economic Returns to the Ganz Collection. John M. Olin Law and Economics Working Paper, No. 76, Second series, The Law School, University of Chicago, Chicago.

Locatelli-Biey, M. \& Zanola, R. (2002). The Sculpture Market: An Adjacent Year Regression Index. Journal of Cultural Economics, 26 (1), 65-78. DOI: 10.1023/A:1013309816736.

Lucińska, A. (2012). Rozwój artystyczny malarzy a ceny obrazów na polskim rynku sztuki. In: Ed. D. Zarzecki. Finanse, Rynki Finansowe, Ubezpieczenia, 51, (pp. 715-725), Zeszyty Naukowe Uniwersytetu Szczecińskiego.

Mc Andrew, C. (2013). TEFAF Art market report 2013 The global art market, with a focus on China and Brazil. The European Fine Art Foundation, TEFAF Maastricht.

Mei, J. \& Moses, M. (2002). Art as an Investment and the Underperformance of Masterpieces. American Economic Review, 92 (5), 1656-1668. DOI: 10.1257/000282802762024719.

Mok, H.M.K., Ko, V.W.K., Woo, S.S.M. \& Kwok, K.Y.S. (1993). Modern Chinese Paintings: An Investment Alternative. Southern Economic Journal, 59 (4), 808-816, www.jstor.org/ stable/1059742.

Nesheim, L. (2006). Hedonic Price Functions. London: CEMMAP.

Pesando, J.E. (1993). Art as an Investment: The Market for Modern Prints. American Economic Review, 83, 1075-1089.

Pesando, J.E. \& Shum, P.M. (1999). The Returns to Picasso's Prints and to Traditional Financial Assets, 1977 to 1996. Journal of Cultural Economics, 23 (3), 183-192. DOI: 10.1023/A:1007595305661.

Renneboog, L. \& Van Houtte, T. (2002). The Monetary Appreciation of Paintings: From Realism to Magritte. Cambridge Journal of Economics, No. 26, 331-357. DOI: 10.1093/ cje/26.3.331.

Renneboog, L. \& Spaenjers, C. (2012). Buying Beauty on Prices and Returns in the Art Market. Management Science, 59 (1), 36-53. DOI: 10.2139/ssrn.1352363.

Sokołowska, E. (2012). Ewolucja i perspektywy rozwoju art investment jako alternatywnej formy inwestowania. In: Ed. M. Piłatowska. Ekonometria dla praktyki (pp. 159-175). Toruń: Polskie Towarzystwo Ekonomiczne.

Triplett, J. (2006). Handbook on Hedonic Indexes and Quality Adjustments in Price Indexes: Special Application to Information Technology Products. Paris: OECD Publishing.

Widłak, M. (2010). Metody wyznaczania hedonicznych indeksów cen jako sposób kontroli zmian jakości dóbr. Wiadomości Statystyczne, 9 (592), 1-25. 
World Wealth Report (2012). Capgemini and RBC Wealth Management, www.capgemini.com/ thought-leadership/world-wealth-report-2013-fromcapgemini-and-rbc-wealth-management (12.11.2013).

Worthington, A.C. \& Higgs, H. (2003). Art as an Investment: Short and Long-Term Comovements in Major Paintings Markets. Empirical Economics, 28 (4), 649-668. DOI: 10.1007/ s00181-003-0152-x.

Worthington, A.C. \& Higgs, H. (2004). Art as an Investment: Risk, Return and Portfolio Diversification in Major Painting Markets. Accounting and Finance, 44, 257-271. 